Archived version from NCDOCKS Institutional Repository http://libres.uncg.edu/ir/asu/

\title{
Appalachỉan
}

B O O N E, N O R T H C A R O L I N A

\section{Weeding With Wisdom: Tuning Deselection Of Print Monographs In Book-Reliant Disciplines}

\author{
By: Alex D. McAllister and Allan Scherlen
}

\begin{abstract}
As university libraries transition to digital collections and new services, their book deselection projects often lead to the adoption of cross-discipline quantitative weeding criteria (such as age and low circulation) in the interest of speed and presumed fairness. Cross-discipline quantitative rubrics, however, can have unintended negative consequences when applied to disciplines such as history and literature that rely on older books with low circulation statistics. The authors argue for a discipline- differentiated approach to weeding academic library collections that can employ quantitative criteria for disciplines, such as in the sciences, that are more reliant on current materials and qualitative criteria for disciplines, such as in the humanities, whose scholars benefit from ready access to older and low-use books.
\end{abstract}

McAllister, Alex D., and Allan Scherlen. 2017. "Weeding with Wisdom: Tuning Deselection of Print Monographs in Book-Reliant Disciplines." Collection Management 42, no. 2: 76-91. Version of record can be found at: http:// dx.doi.org/10.1080/01462679.2017.1299657 
Alex D. McAllister \& Allan Scherlen (2017): Weeding with Wisdom: Tuning Deselection of Print

Monographs in Book-Reliant Disciplines, Collection Management, 42:17 pp. 76-91. DOI:

10.1080/01462679.2017.1299657 To link to this article:

http://dx.doi.org/10.1080/01462679.2017.1299657

\title{
Weeding with Wisdom: \\ Tuning Deselection of Print Monographs in Book-Reliant Disciplines
}

\author{
Alex D. McAllister and Allan Scherlen \\ Appalachian State University, Boone, North Carolina
}

\begin{abstract}
As university libraries transition to digital collections and new services, their book deselection projects often lead to the adoption of cross-discipline quantitative weeding criteria (such as age and low circulation) in the interest of speed and presumed fairness. Cross-discipline quantitative rubrics, however, can have unintended negative consequences when applied to disciplines such as history and literature that rely on older books with low circulation statistics. The authors argue for a disciplinedifferentiated approach to weeding academic library collections that can employ quantitative criteria for disciplines, such as in the sciences, that are more reliant on current materials and qualitative criteria for disciplines, such as in the humanities, whose scholars benefit from ready access to older and low-use books.
\end{abstract}

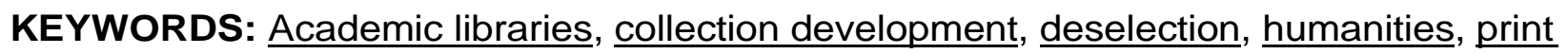
books 


\section{Introduction}

\section{The zeitgeist of massive weeding in academic libraries}

Many academic libraries across the country are rapidly reducing their print collec- tions and shifting their efforts to e-books and new services. A recent e-mail from the library e-book vendor ProQuest announced that out of more than 400 librarians surveyed, $78 \%$ of the respondents reported that they are deselecting print book collections and "reclaiming shelf space to off $r$ some other form of collaborative space or lab" (Mullarkey 2016). University scholars outside of the library may be surprised to learn that so many libraries are undertaking massive book deselection projects, and the impact of this trend may not be felt until researchers discover that their own library has been pulling books from the shelves. Then a conflict between the library and university faculty can arise, even leading to the perception of the library as uncooperative with faculty or insensitive to their research and curricular book resource needs (Howard 2009; Meliker 2009, Terruso 2009). But univer- sity librarians, especially those in collection development, are currently confronting serious issues related to reducing their print book collections as they respond to pressures from tightening book stacks, expanding e-book duplication, and the need to make space for new library functions. The library literature on deselecting university collections, however, can be confusing and inadequate, often leading to the adoption of criteria that disadvantages the more book-reliant disciplines. Therefore, academic librarians need to consider qualitative criteria for deselection that is fine- tuned throughout the process to be sure that they are serving the best interests of bookreliant disciplines, such as those in the humanities.

It is understandable that academic librarians are quick to reduce their print collections. Many are ready to unburden themselves from the mantle of the "protectors of the book" and to move on to embrace new e-resource and service functions. Librarians want to remain relevant in what is foreseen as a future increasingly devoid of print resources, where libraries provide new and diff rent kinds of services and content.

These new roles include becoming campus guardians of group study spaces and maker technologies, such as 3-D printing and robotics. Book stacks that show decreasing circulation statistics can arguably be seen as occupying coveted space better utilized by more seating and new services.

One needs to only attend any national collection development library conference to see the pervasive trend toward revamping library space through rapid and massive weeding. A review of Charleston Conference presentations over the past few years will yield such titles as "Speed Weed: How We Weeded More Than 70,000 Items in Three Months" (Johnston and Remhof 2011), "Less Is More: Origins of Univer- sity of Wisconsin-Stevens Point Collection Assessment Plan" (Reich 2013), and oth- ers that announce the broad deselection of books to transition university libraries "to becoming educational services centers," as the authors of "Weeding One STEPP at a Time" (Cook, Shouse, and Thomas 2012) and others informed their librarian colleagues.

At this point, one might be quick to quip, "library weeding is not new." And yes, academic libraries have been culling their book collections for decades, and the tra- 
ditional reason for doing so has generally been the need to make room for new monographs and to remove duplicate, superseded, or outdated materials. But while these purposes are still often mentioned, we are increasingly seeing new reasons for removing print materials and shelving such as the assumptions that libraries are better served by e-books and digital collections or that floor space can be better utilized for services such as group study areas (Arbeeny and Chittenden 2014; Acadia 2016). Whatever the current driving purposes behind academic libraries deciding to undergo major weeding projects, they too often follow a deselection plan that appears efficient and consistent across the disciplines by employing criteria such as circulation, age, and other measurable data (Snyder 2014). But broadly applied rubrics, as argued in this article, can adversely affect the research needs of bookreliant disciplines.

Therefore, this article, informed by experience with a major weeding project and input from faculty in the humanities and social sciences, is a call for university librarians to seriously consider discipline-specific, user-inclusive procedures before conducting a deselection project. While the argument for treating disciplines differently when weeding print materials may seem self-evident to many collection development librarians, the emergence of massive weeding projects that do not take discipline differentiation into account show that this important consideration may be getting overlooked. Moreover, in light of becoming aware of varying disciplinary book needs, the authors argue for carefully considered criteria in consultation with faculty members in monographic intense disciplines who understand the mono- graphic needs of that discipline rather than imposing a one-size-fits-all quantitative criteria to reduce a print book collection across disciplines.

\section{A midsized academic library faces its weeding mandate}

The authors of this article became acutely aware of this academic library priority shift toward radically reducing the print collection in 2015 when their midsized university library, like so many others around the country, embarked on a major building renewal project to make room for new and expanded services with an associated intensive book deselection component. The project arose as the library sought to revitalize itself with expanded technology offerings, a makerspace, an "experimental" classroom, expanded archives, more seating and lounges, and a larger writing center. An architectural firm was hired to meet with the building project team. From the architects' calculations, a significant number of books had to be removed to make space for the proposed services. An initial plan was formed by a dean-appointed team, with a single deselection criterion for the entire monograph collection: Books added to the catalog before 1995 that showed no apparent circulation activity in the past 20 years were candidates for withdrawal. The list generated from the Sierra Integrated Library System (ILS) using these criteria rendered approximately 90,000 titles to review. After collection librarians identified obvious core items to retain, about 70,000 print books remained on the list. The initial plan was to complete the deselection project in less than a year. For the project to stay on a one-year schedule, the project team calculated that collection development librarians needed to remove approximately four book trucks per week of approximately one hundred items per truck. This pace, added onto other faculty librarian work, made thorough scrutiny of individual titles difficult. 
When the campus learned of the planned project, a number of faculty members became concerned about the possible loss of important print materials. They argued that faculty, even at midsized universities, are expected to do competitive research and need to participate in reviewing library materials being deselected. In response to their request, the library posted an online basic author/title list and gave the faculty approximately two months to notate titles found on the approximately 70,000- item list for retention. There were 215 responses from faculty and the largest number of requests to save items were for books in the subject areas of English and history. Below are some responses from faculty who filled out the request to save books on the title list:

- Many of these books are first editions and should be in special collections [;] others are secondary criticism but old enough to not likely to be on Google books.

- Classics in the field and, in some cases, primary source materials. I have submitted multiple lists and strongly urge the library to retain these books-in an annex, if necessary. They are of considerable intellectual and financial value to our campus.

- The books on this list are CRUCIAL. I cited most of them within the last two years. PLEASE do not discard these titles.

- These titles in premodern political thought are classics within the field and should be retained for faculty and student research (McAllister and Scherlen 2016).

The library also agreed to the Faculty Senate request, originating from departments in the humanities, to allow faculty to review trucks of weeded books in a reviewing room after collection development librarians made a first pass. Faculty were offered two options: Return books to the main stacks or send books to their department. Books that did not fall into either option were to be deselected and sent to the Office of Sustainability for a book sale, donation to developing countries, or recycling. The added step of allowing faculty to review carts of books eased concerns among scholars on campus and indeed helped recover important but obscure titles that librarians with even a deep knowledge of the bibliography of the discipline missed. For example, a faculty member asked to keep a work of Orestes A. Brownson, a New England intellectual and labor organizer affiliated with the New England Transcendentalists. Another asked to keep a book by Max Black, a British- American philosopher who was a figure in analytic philosophy in the first half of the twentieth century. Two other examples of books recovered through the cart review process were titles by David Knowles (b. 1896), whose works on monasticism in England through the dissolution of the monasteries are considered authoritative, and Max Müller, who was one of the founders of the western academic field of Indian studies and the discipline of comparative religion. Although the quantity of books saved by faculty review was not significantly large, the library benefited by identifying important titles, reducing concerns on campus about the project, and creating new relationships between librarians and faculty who had not been engaged with the library in the past.

Faculty who participated in the deselection process by coming to the library to look at books provided useful comments. One faculty member said:

I think the library needs to take into account how different disciplines use books. For historians, oftentimes the older a book is, the more important it becomes as a primary source. It should be remembered too that just because a book has not been regularly checked out doesn't mean that it is worthy of being discarded. Nor 
can the past records of how often the book has been checked out determine its future importance. Most importantly, the library must work with the faculty closely in conserving and improving these most valuable resources. (McAllister and Scherlen 2016)

Another faculty member commented:

I encourage you to tread carefully and transparently in curating the university's collections of scholarly resources. In the humanities and some social sciences, old things, even infrequently used ones, have value. Our university was founded folks in our region to the world through education, and the library represents that font of knowledge. Please do not let budget constraints promote a return to a culture of ignorance. (McAllister and Scherlen 2016)

The authors discovered from faculty comments that the weeding project was met with opposition from the same disciplines as other university libraries that underwent a similar intensive weeding project, namely the humanities and humanistic areas of the social sciences. It became evident that they used books differently and that better communication was necessary with faculty to understand their actual monographic needs and concerns. By conducting informal interviews with faculty, reviewing their e-mails and comments, and studying literature on mono- graphic use in the humanities, the authors gained a better understanding about retaining print monographs in the humanities and related disciplines. Consequently, the authors learned that a one-size-fits-all criterion review lacked understanding of monographic research needs in book-intensive disciplines.

\section{Literature review}

A review of recent library literature shows a trend toward administratively driven deselection projects in academic libraries relying on generic quantitative criteria such as circulation statistics and age of materials (Snyder 2014). But the planners of those mega-weeding projects should not be surprised when they encounter resistance from book-centric scholars who argue for the retention of older, lesserused volumes to support their curricula and research. Inevitably, as the authors' discovered, the humanities faculty members and other users of older books can become very concerned about "the loss of their books" and ask for adjustments to the weeding criteria to accommodate their need for some categories of low-use but important books.

Of interest, library literature shows that less-than-positive reactions by librarians to professors wanting input into deselection of their book resources is common. Hence, there are plenty of articles offering librarian-to-librarian inside advice on controlling patron reactions and maintaining resolve against naysayers to assure completion of the weeding project (Metz and Gray 2005; Intner 2006; McCormack 2008; Young 2009; Lynd 2015). And too many weeding-related publications, it was discovered, are unfortunately short on self-criticism and long on anecdotes, cheerleading, and misplaced confidence, avoiding the uncomfortable question of whether users might be appropriate participants in the deselection process (Handis 2007; Raphael 2013). So, although it is easy to find professional literature addressing morale-building support for 
libraries culling their collections - much of it writ- ten by and for public librariessurprisingly little guidance is provided to academic libraries of any size for determining a set of deselection criteria that are fair to each discipline's particular use of and need for print books. Also lacking in the literature is a conceptual, discipline-specific framework to be used for the planning and execution of a large-scale project. Moreover, the library literature on writing collection development policies, where deselection guidelines for each discipline would logically reside, generally does not address the value of documenting deselection criteria according to specific, disciplinary needs beyond very general statements (Hoffman and Wood 2005).

Stanley J. Slote produced some of the first writings on the subject of library weeding and is considered by many to be a seminal author on the subject. His book, Weed- ing Library Collections: Library Weeding Methods, seeks to "overcome our natural reluctance to weed by making the process simpler, more objective, and more scientific" (Slote 1997, xvii). The line of authors who make claims for a scientifically based weeding model often draw from Slote's narrowly focused study of public libraries that was first published in 1975. An early study by Allen Kent asserted that $40 \%$ of books at the University of Pittsburgh were never used (Kent et al. 1979). Accord- ing to Fry, this assumption that many books acquired by libraries are never used has been perpetuated by many in the weeding literature since, including Rick Lugg (2009) and Dennis Dillon (2001), who argued "that traditional collection development had failed and called for libraries to shift half of their collection of print and electronic books to PDA [patron-driven acquisition]" (Fry 2015, 3). Fry noted that both have been cited in the literature. "As with many who would later repeat this idea, Lugg and Dillon cited little data to support it," Fry explained (4).

Fry debunks a myth spawned from that influential University of Pittsburgh study that asserted that a large percentage of books acquired by libraries are never used. She explains that circulation statistics only provide one variable and fail to consider important issues like collection size, when an item was purchased, or subject distribution. Fry cites O'Neill and Gammon, who performed an OhioLINK-OCLC circulation study, explaining that "low-circulating items do not necessarily reach a point where they become of no use" (Fry 2015, 6). The study also found that OhioLINK library books older than 70 years circulated as much as recently published titles. Fry presents numerous other examples that show a significant percentage of academic library print books circulating. These studies stand out as recent examples, in contrast to many articles that continue to rely on Kent et al.'s 1979 questionable assumption that many university books do not circulate in order to justify employ- ing scientific deselection criteria to clear the chaff.

Surprisingly, studies critical of the conventional wisdom around weeding such as Fry's are easily ignored when libraries embark on extensive weeding projects. Rather than consider pertinent information such as what a book is about or who may need it, it is perhaps just easier to adopt a largely data-driven method of weeding such as proposed by Slote. Such quantitative approaches to weeding have not been discouraged by a publishing industry that is eager to replace print with e-book packages and, as Fry explains, eager to "control content" (Fry 2015, 19). In an increasingly technologically driven, STEM-influenced, and profit-focused world where librarians feel the need to justify how they will remain relevant in libraries without physical collections, there is an 
evident lack of more fundamental discussion about how libraries will continue to be relevant in traditional, or foundational, functions of academic library research. But concern for new relevance can become a major impetus propelling massive removal of books to make room for new services, which in turn can set off a negative reaction by the very library users intended to be served. Library literature too often looks upon these negative effects as public relations problems rather than possible mistakes in library decision-making and process.

\section{Library liaison and user reactions to weeding}

One of the most cited articles on weeding is Paul Metz and Caryl Gray's "Public Relations and Library Weeding" (2005). Metz and Gray published a study about a large deselection project that took place at the Virginia Tech University Libraries between 1995 and 2002. They focus on public relations and share their experiences as well as their "sensible criteria" (Metz and Gray 2005). Their criteria for deselecting monographs include "any book of low relevance and value" (277). They argue that weed- ing is necessary because of pressure from funders and policy makers and a "shifted emphasis in research away from the humanities disciplines towards scientific and technical disciplines whose materials lose their value more quickly" (273-274). They cite a 2003 column in American Libraries by Will Manley, who asked, "If weeding is so important, why is it so neglected?" adding that it deviates from the librarian perspective of "savers, preservers, and defenders of the written word" (Metz and Gray 2005, 273). Metz and Gray further cite Will Manley, who contended in 2003 (arguing from a few public library case examples) that librarians want to weed but fear political consequences associated with weeding, advising that "it's good to keep your weeding program obscure and out of the public eye" (276). But in a university, where library resources are closely tied to curricula and research of that community, is not transparency of the process an essential component?

Spencer Acadia (2016) published one of the most recent case studies on university library weeding, dedicating only a small paragraph to gaining support from university faculty. The article does not cite Metz and Gray but does express the importance of working with faculty to alleviate fears. Still, like other studies, the need for a detailed level of discipline differentiation in developing deselection criteria was not addressed. He was comfortable using quantitative weeding criteria tempered with "good intentions" in the spirit of Metz and Gray rather than creating a more thorough process to identify important books to retain in the humanities and similar disciplines. In the case of the University of Texas at Tyler, Acadia notes that the library was part of a shared storage facility called the Joint Library Facility. Off-site storage facilities are excellent options for libraries that have such access, but the University of Texas at Tyler still weeded half of its entire print collection during a period of less than one year, an amazing feat for any library in such a short amount of time. Acadia expressed concerns in a table of pros and cons to reduce their collection by $50 \%$. Bullet points against such radical reduction included "Immediate access to 66,000 titles was lost as a result of the massive deselection process" and "Faculty and student resistance to massive purging of books" (Acadia 2016, 152). An important feature of the University of Texas at Tyler weeding project was that each department "liaison set her or his own weeding criteria 
that were judged to be most appropriate for their discipline" (147) and "the thresholds for each [discipline] varied. For example, cri- teria for weeding in computer science was more aggressive than sociology, because computer science titles become out-of-date much more quickly" (147).

The theme of faculty and student resistance to weeding projects repeatedly surfaces in the literature. Metz and Gray were not the first to address the issue (Harloe 1984; Pidgeon 1995; Eberhart 2001). Although Metz and Gray do not provide an extensive literature review for their case study, they do mention an important earlier author, Bart Harloe. In 1984, Harloe published an article titled "The Politics of Weeding: New Myths and Old Realities: Myths and Realities." Like Metz and Gray, Harloe wrote about the public relations of weeding and collaborating with university departments in working through the project, which he argued "was absolutely crucial" (Harloe 1984, 266). Harloe's University of Pacific Library deployed their liaisons to increase faculty participation. His hope was that this outreach would "encourage meaningful faculty participation in the collection review process" to alleviate concerns with weeding books (265). In a section where Harloe discusses teaching faculty involvement, he mentions that librarians were unable to counter "the argument that some books are used at the shelf and returned directly to the shelf "(266). There is a clear argument that Harloe is pursuing in the article: Teach- ing faculty are pertinent to making better decisions about weeding a title, tracing this position back to a book from 1969 titled, Patterns in the Use of Books in Large Research Libraries (Fussler and Simon 1969). "There is little question that the over- all effectiveness of any formula for selecting books for storage would be improved considerably if one or more scholars reviewed the titles recommended for storage" (Fussler and Simon 1969, 270). While much has changed since 1969, many humanists make this argument for faculty participation today, as Acadia remarked: "Faculty support and cooperation in any academic library project of this magnitude is useful" $(2016,153)$.

Metz and Gray (2005) believe in the importance of appearing to "do the right thing" with faculty, but then concede that they deselect as the library deems necessary. They also state that the VT Libraries "deflected potential criticism from environmentalists by recycling" books. This advocacy for circumventing faculty input implies that their intentions for good public relations is really about navigating a hurdle or barricade that threatens the weeding project. Harloe, on the other hand, promotes an appreciative understanding of the expertise university faculty can offer to libraries in deselection projects.

Still, there is value in the Metz and Gray article, and it is commendable that the librarians who deselected books in that project made decisions with the "book in hand" (Metz and Gray 2005, 275). There is, however, reason to be concerned that academic libraries may feel compelled to remove thousands of books with little more criteria than circulation statistics and age of holdings. Fry has presented a clear argument against the over-expedient method of removing books based on circulation data alone. It is also evident from the ProQuest survey mentioned in the introduc- tion that if such a large percentage of libraries are deselecting print books, the num- ber of holdings listed in WorldCat (OCLC), the database used by libraries for interli- brary loan, will diminish. Librarians should consider Harloe's arguments for faculty needs for print 
books rather than regarding faculty members as obstacles to be man- aged through public relations.

Librarians remain surprisingly cautious about inviting teaching faculty to assist in weeding projects, however. They express fear that faculty will claim that too many items should be saved, although this is rarely the case (Handis 2007). Michael Han- dis wrote a case study on weeding a small academic library, where he noted that the "teaching faculty has a vested interest in the library" (86). Handis adds that the faculty want an abundance of materials to work with in their field. He, however, believes that librarians are better suited than teaching faculty to making weeding decisions because "Librarians are trained to take the entire collection into account" (86). Is this a professional hubris that is at the heart of much librarian resistance to including faculty in the process? Handis presents an example of a faculty member who requested saving every book in a specific subject area to imply that this single example occurs as the rule in faculty reviews. There is some truth in Handis' belief that librarians' daily experience better equips them to evaluate the overall collection. There is also truth, however, in the fact that teaching faculty have a deeper historical understanding of their research areas of the collection and may be more engaged with books in their subject areas needed for their curricula and their research. Handis misses the crucial issue, focusing instead on who is more qualified to determine whether books should be saved. The question he might have better asked is, "Which books should be saved, and why are these books important to their disciplinary field?" Instead, he invokes a quote from Sheila Intner to belittle those who want to keep books as mere hoarders: "This notion, that weeding destroys valuable library materials, is both false and dangerous. It flies in the face of reality and encourages the pack rats among us to force everybody to bow down to clutter, no matter how unappealing it makes their libraries or how discouraging and inefficient their collections become to patrons." (Intner 2006, 15). Such volatile accusations may embolden those librarians intent on pushing big weeding projects, but they ignore and defy the fundamental disciplinary differences in book needs that librarians should try to understand. Of course it is unreasonable to save every book, and nobody is advocating for that, especially in times of space needs and expanding online sources, but careful steps should be taken to determine whether a book should be saved or discarded based on the individual book's value to the current and potential research needs of the faculty and students of that discipline.

\section{The interlibrary loan argument for deselecting useful books}

David Woolwine published a seminal article in 2014 refuting the idea that inter- library loan "may allow for rapid de-accession of much of local academic print titles" (Woolwine 2014, 2). Contrary to the belief that holdings by other libraries, and thus availability through interlibrary loan, will allow librarians to purge their local book collections, Woolwine argues that "such beliefs are not based on a thorough consideration of the scholarly and teaching needs of even smaller aca- demic institutions and that the process of further transition should be a care- ful one, best thought of as proceeding in a step-wise fashion" (2). In fact, Wool- wine predicts a day 
where the large academic libraries, which smaller libraries depend on for borrowing, will be strained to meet the needs of interlibrary loan requests, especially if large research libraries also massively shift to e-books and many midsized and smaller libraries continue to deselect their print collections. He suggests that this could lead to restrictions on interlibrary-loaned items. Wool- wine argues then that even smaller libraries need their print book collections and should judiciously deselect with much thought directed to the curricula and methods of scholarly book research used by each discipline, especially in the humanities.

\section{The book research needs of the humanities and humanistic social sciences}

One of the most important works on humanistic research in libraries is Berhnard Fabian and John J. Boll's In Close Association: Research, Humanities, and the Library (1998). Fabian and Boll have an insightful perspective on humanistic research and understand the value of printed monographs both current and historical. They explain that other types of materials (i.e., journal articles, primary sources, etc.) are relevant to humanities research, but it is the printed book that is the major tool for most disciplines in the humanities. They conclude that "it is axiomatic that the more a library's resources represent recorded knowledge-i.e., the richer its historical resources, along with an adequate supply of modern scholarly literature-the better prerequisites it supplies for scholarly work" (7). Fabian and Boll go on to explain that the library has a different function when it comes to the humanities as opposed to the natural sciences:

Its task is not only to store and make available scholarly literature (seen in the narrow sense) for purposes of research, its function (and in many respects its primary function) is also to accumulate and present the resources that are required for the research process itself. Libraries make available for future use the source material needed for scholarly work as well as the existing products of this work. The library's "simple" storage function, as viewed from the perspective of the natural sciences[,] expands under humanistic premises and, in turn, gains a historical dimension. The library keeps the character of an archive of modern scholarly literature but, simultaneously, becomes a scholarship-serving archive of cultural traditions (7).

Fabian and Boll present a lengthy argument for the need for historical materials that do not frequently circulate using the metaphor of a laboratory. Just as natural sciences require a laboratory with all of the necessary instruments to carry out research, so too do humanities researchers require an "institutional apparatus" equipped with the necessary print materials (Fabian and Boll 1998, 10). "Therefore, the richness and accessibility of library resources cannot be considered a mere incidental or marginal aspect of scholarly work-they are an essential requirement for research" (Fabian and Boll 1998, 11). Other studies provide a focus on the research practices of humanities scholars in the age of e-books, but more research is needed on the subject of weeding books in the humanities (Martin and Quan-Haase 2013). 


\section{The problem of using quantitative criteria when deselecting books in the humanities}

Applying quantitative, "scientific" weeding criteria, such as low circulation and publication date parameters, across all the disciplines may be argued by libraries as a seemingly fair and measurable method for judging which books are valuable across disciplines. Librarians point to science, health, and business scholars who rely on more recent publications usually found in journal literature and data. But humanities research is very different in that it is more reliant on older, low-use books. Woolwine notes the quantitative bias in the tra- ditional deselection commentary of Slote (1997), Banks (2002), Lugg (2012), and Snyder (2014), who advocate for criteria such as usage data to determine whether a print book should be weeded. Woolwine states: "Professional judgment of the librarian informed by knowledge of other factors is more important than such information [usage data] in making de-accession decisions" (Woolwine 2014, 3).

Woolwine provides many examples of discipline-specific book usage found in the literature of humanities research methods. Woolwine argues that many humanities scholars benefit from exploring the stacks as part of their research method. This includes the discovery of unknowns in the collection, revealing "holes" in prior research, which "can be determined only by reading." He further observes that humanities researchers use methods such as "grazing" and following passages and citations (Woolwine 2014, 8-9). He especially focuses on the articles by the historian Robert Darnton in the New York Review of Books in 2008, who discusses the physical experience of working with print books, and by Andrew Abbott, a sociologist from the University of Chicago who addresses humanistic social science and humanities book research. Abbott deconstructs the various vital elements of human- istic research: "Questions, answers, sources, and information are simultaneously in play in a library research project. There is no separation of design and execution" (Abbott $2008,525)$. Abbott then argues that books function as indirect indexes pro- viding references to other books and articles. Woolwine elucidates that "the order" of books within a library and "the order" of humanities-based research is constructed by human algorithms. "Such order is 'idiosyncratic' and, in fact, there are multiple simultaneous orderings in the library if we take the references and quotations within books as also creating an order." Woolwine adds: "In humanistic scholarship prior research is central. Reading and browsing (in whatever sense) are the major prac- tices of such researchers with multiple meanings present and generated" (Woolwine 2014, 8).

Abbott argues that new research spawns from prior research, and Woolwine posits that the breadth of a collection is necessary to afford access to such prior research, particularly in the humanities. Still, unless one is a humanities researcher or somehow involved in research in the humanities, the needs of these disciplines for older, lesser-used books may be overlooked. Libraries moving swiftly to dese- lect with brittle criteria based on quantitative rubrics alone can miss these critical 
disciplinary research issues that should be considered before dismantling a humanities collection.

Consider the commonly held position that Victor Oliva recently wrote: "If a circulating title has not been charged out for home use in the previous 20 years, then it is unlikely it will be missed if it is discarded" (Oliva 2016, 38). Of course, an item that is discarded can be missed if it is removed from a library leaving fewer or no materials on a subject. If a U.S. Revolutionary War historian seeks information about Henry Knox, for example, but only has access to one monograph on Knox because the others were removed after twenty years of no checkouts, that researcher's process is directly affcted. The researcher may even remember using some of those missing Knox books in the past, but now is penalized for simply placing them back on the shelf without recording a circulation tick.

The popularity of research topics are often cyclical, going in and out of fash- ion and relevance. It is difficult for librarians to predict when or whether low-use items will become relevant again. Recent concern for police violence, for example, can restimulate interest in the publications from the Civil Rights era. Oliva, rather than being pessimistic in declaring "weeding the collection a hopeless task," should embrace the potential of humanities collections (Oliva 2016, 38). The process should be approached in collaboration with faculty experts in considering potential use by book-dependent disciplines. Oliva asks a question at the end of his article: "Should we choose a timeframe of fewer than fifty years to review titles in some areas of the social sciences and humanities?" (46). It is very possible that some of those older books from fifty years ago weeded at Oliva's library included important historical information to various fields in the social sciences and the humanities. The tendency for libraries to pick an arbitrary number of years such as fifty, twenty, or ten has only exacerbated the problem of ignoring disciplinary differences.

Pamela Arbeeny and Lloyd Chittenden published a weeding case study at Fort Lewis College. Because of space needs, librarians were asked by the library director to weed 4,000 to 5,000 books during the summer. Librarians checked for core titles using Resources for College Libraries; however, there was no mention of using additional sources such as WorldCat or even Wikipedia to discover information about lesser-known topics or authors. Arbeeny and Chittenden state that the library created a list of "20,974 [books] that had zero checkouts since 2003," or about ten years with no apparent circulation $(2014,80)$. The Fort Lewis College weeding project did take into account changing curricula. The college was eliminating the agriculture and computer science programs, which allowed librarians to remove much of the material in these subjects, although some recent and core works in agriculture and computer science were retained. By considering disciplinary connections to the curricula, Arbeeny and Chittenden did attempt to consider disciplinary needs. They note about their weeding project: "Despite the limited use of the titles under review, the authors felt that literature, music, and their criticism were, by their nature, less likely to be dated and more likely to be of relevance to future patrons" (Arbeeny and Chittenden 2014, 85). As the case of Fort Lewis and elsewhere show, librarians often receive weeding mandates from campus or library 
administration, with an emphasis on moving quickly. The librarians then may be inclined to follow formulas for a quick and seemingly fair process, but the Arbeeny and Chittenden article illustrates how an understanding of the curriculum at an institution, in addition to the varying types of disciplinary researchers who most frequently use the collections, will improve the process.

Just as important as considering the history within library literature on techniques for book deselection, librarians preparing to weed collections should also be wary of the historical and philosophical influences that lack an understanding of humanities research methods. Loriene Roy references Charles William Eliot, president of Harvard University from 1869 to 1909, who attended the twenty-fourth Annual American Library Association Meeting in 1900 and spoke about solutions to space problems. "Instead of suggesting that libraries continue to respond to the space problem by constructing additions to existing buildings, Eliot called on librarians to adopt a novel perspective in surveying their collections," adding, "Henceforth, all books were to be considered living or dead" (Roy 1988, 144). Further research into Eliot's background reveals he was a serious student of math and science. His studies of educational institutions in Europe were conducted through a businesslike, administrative lens. "Eliot's contribution to the philosophy of weeding was to establish actual use rather than possible usefulness as a criterion for identifying items that could be culled from the collection," Roy said (145). Thus the problem of relying on quantitative criteria was initiated as early as the turn of the twentieth century. One has to wonder what Charles William Eliot's cousin, Nobel Prize-winning poet T.S. Eliot, might have thought about this philosophical view of each book being declared dead or alive, since he was so dedicated to the importance of libraries and connecting to obscure literature of the past. "Our problem being to form the future, we can only form it on the materials of the past; we must use our heredity, instead of denying it" (Eliot 1932, 385).

Fabian and Boll would most certainly agree that all humanities books are alive. They would likely also agree that the manner in which humanities texts are used differs from other disciplines and require careful scrutiny before being deselected. "The availability of scholarly literature is a prerequisite for scholarly work," Fabian and Boll said, adding, "A venture beyond this trivial observation reveals insufficient recognition of the fact that scholarship makes diverse demands on literature which must, and can, be satisfied in various ways" (Fabian and Boll 1998, 5). They said libraries make the mistake of having a "monistic premise" for determining what literature is retained. "But the demands of scholarly work differ in differ- ent domains, and even within one domain they need not remain static. Since the needs for bibliographic resources are variable, expectations regarding the institu- tions that supply the resources cannot be uniform" (5). Many libraries that are mas- sively weeding their collections are doing so based on the monistic premise Fabian and Boll describe. At a time when more and more libraries are purging collections, we should heed the warning of Fabian and Boll and humanities researchers to create disciplinarydifferentiated criteria for deselection rather than falling back on "scien- tific" criteria as a blanket solution. 


\section{Developing disciplinary criteria for deselection}

So, how do we take humanities research methods into account as we reduce our burgeoning book collections? Certainly, the first step is to consider developing disciplinary criteria for deselection. It is hoped that librarians will work with faculty in the subject areas of books being evaluated to better determine their own procedures for qualitatively assessing books in their academic libraries.

Some disciplines in the social sciences and areas of the sciences may have scholars who use books in similar ways to those in the humanities, and it is recommended that librarians apply relevant criteria to any discipline that indicates need for older, lowcirculation print books. Because of the qualitative nature of such an approach to weeding the humanities and other humanistic disciplines, the process in deselecting materials will take longer and involve more people than when using a set of blanket criteria such as weeding everything more than ten years old that has not circulated. It may also require that subject librarians at academic libraries collaborate with expert faculty members when conducting major weeding projects of a subject to gain insights from those who are especially familiar with early works in the areas being reviewed.

\section{Conclusions}

As more university libraries choose to reduce print collections to accommodate change in library services and functions, be it for space reallocation, technological installations, or as yet unforeseen purposes, it is important that librarians apply discipline-specific qualitative criteria when weeding more book-centered disciplines such as those in the humanities. To address deselection of books in art, history, literature, or other humanistic fields with the same across-the-board quantitative criteria as used to deselect books in business, health, or the sciences is as unfair as determining science journal budgets based on the lower journal pricing of humanities. Universities can certainly use mixed criteria that employ a stricter quantitative rubric for disciplines that rely more on current and/or non-book resources and disciplinespecific, qualitative criteria well-tuned for subjects that have a genuine need for older, lesser-used books in their research and teaching.

The authors hope that with this presentation of the need for deselection guidance as revealed in both humanities and library literature and from their experience at a time when many academic libraries are undergoing major renewal projects, academic librarians will consider the importance of carefully differentiating print book needs among disciplines when deselecting books in their university library. Adopting a discipline-differentiated approach for deselection will bring balance to the process, allowing for the weeding of what can go and saving what should reasonably be retained, resulting in a better overall library collection that serves all of the disciplines appropriately. Further research is needed to develop more formal models of deselecting monographs in humanistic disciplines. Of course, it is important to be good stewards of library resources while transitioning to new services and technologies, but we must remember Bart Harloe's advice back in 1984 to "not forget a very important lesson: in the final analysis, 'objective procedures' alone are insufficient because the collection review process needs to be continuously guided by active 
human judgment" (Harloe 1984, 267).

\section{References}

Abbott, Andrew. 2008. "The Traditional Future: A Computational Theory of Library Research."College \& Research Libraries 69 (6): 524-545.

Acadia, Spencer. 2016. "Books Be Gone! Reducing an Academic Library's Print Collection by Half to Meet Strategic Planning Initiatives and Participate in a Joint Library Resource-Sharing Facility." Journal of Library Administration 56 (2): 144157.

Arbeeny, Pamela, and Lloyd Chittenden. 2014. "An Ugly Weed: Innovative Deselection to Address a Shelf Space Crisis." Journal of Library Innovation 5 (1): 78.

Banks, Julie. 2002. "Weeding Book Collections in the Age of the Internet." Collection Building 21 (3): 113-119.

Cook, Eleanor, Dan Shouse, and William Joseph Thomas. 2011. "Weeding One STEPP at a Time."Proceedings of the Charleston Library Conference. doi.org/10.5703/1288284314903

Darnton, Robert. 2008. "The Library in the New Age." New York Review of Books, 10 (55).

Dillon, Dennis. 2001. "E-books: The University of Texas Experience, Part 1." Library Hi Tech 19 (2): 113-124.

Eberhart, George M. 2001. "Furor Erupts Over Chicago Weeding Program." American Libraries32 (9): 22-25.

Eliot, T. S. 1932. Selected Essays 1917-1932. New York, NY: Harcourt, Brace and Company.

Fabian, Bernhard, and John J. Boll. 1998. In Close Association: The Humanities, Research, and the Library. Champaign, IL: University of Illinois, Graduate School of Library and Information Science.

Fry, Amy. 2015. "Conventional Wisdom or Faulty Logic? The Recent Literature on Mono- graph Use and E-book Acquisition." Library Philosophy and Practice (ejournal). Paper 1307 accessed on March 10, 2017, from http://digitalcommons.unl.edu/libphilprac/1307/

Fussler, Herman Howe, and Julian Lincoln Simon. 1969. Patterns in the Use of Books in Large Research Libraries. Chicago, IL: University of Chicago Press.

Handis, Michael W. 2007. "Practical Advice for Weeding in Small Academic Libraries." Collection Building 26 (3): 84-87. 
Harloe, Bart. 1984. "The Politics of Weeding: New Myths and Old Realities in Academic Libraries: Myths and Realities." Proceedings of the Third National Conference of the Association of College and Research Libraries 4-7 (April): 263-268. Association of College and Research Libraries Chicago.

Hoffmann, Frank W., and R. J. Wood. 2005. Library Collection Development Policies: Academic, Public, and Special Libraries. Lanham, MD: Scarecrow Press.

Howard, Jennifer. 2009. "In Face of Professors' 'Fury,' Syracuse U. Library Will Keep Books on Shelves." The Chronicle of Higher Education, Nov. 12. Accessed March 10, 2017. http://chronicle.com/article/In-Face-of-Professors-Fury/49133/

Intner, Sheila S. 2006. "Weeding, Collection Development, and Preservation." Technicalities 26 (3): 1-18.

Johnston, Gail, and Tamara Remhof. 2011. "Speed Weed: How We Weeded More Than 70,000 Items in Three Months." Proceedings of the Charleston Library Conference. doi.org/ 10.5703/1288284314907

Kent, Allen, Jacob Cohen, K. Leon Montgomery, James G. Williams, Stephen Bulick, Roger R. Flynn, William N. Sabor, and Una Mansfield. 1979. Use of Library Materials: The University of Pittsburgh Study. New York, NY: Marcel Dekker.

Lugg, Rick. 2009. "Expert Selection \& Monographs Use: A Brief History (and a Brief Future?)." Lecture, Bloomington, IN, May 19. Accessed May 15, 2015. http://citeseerx.ist.psu. edu/viewdoc/download?doi=10.1.1.372.6527\&rep=rep1\&type=pdf

Lynd, Hillary Barbara. 2015. "Managing Print-Based Weeding Projects in Academic Libraries." Dalhousie Journal of Interdisciplinary Management 11. doi.org/10.5931/djim.v11i0.5516

Martin, Kim, and Anabel Quan-Haase. 2013. "Are E-Books Replacing Print Books? Tradition, Serendipity, and Opportunity in the Adoption and Use of E-Books for Historical Research and Teaching." Journal of the American Society for Information Science \& Technology 64 (5): 1016-1028.

McAllister, Alex, and Allan Scherlen. 2016. Deselection project field notes from online responses including e-mails and personal comments 2016-2017.

McCormack, Nancy. 2008. "When Weeding Hits the Headlines: How to Stop Your Library From Making that Kind of News." Feliciter 54 (6): 277-278.

Meliker, Shayna. 2009. "University Senate: Students, Members Debate Book Removal Program." The Daily Orange. Accessed March 10, 2017. http://dailyorange.com/2009/11/university- senate-students-members-debate-bookremoval-program/

Metz, Paul, and Caryl Gray. 2005. "Public Relations and Library Weeding." Journal of 
Academic Librarianship 31 (3): 273-279.

Mullarkey, Marty. 2016. "Last Chance! Participate in Space Reclamation Survey." ProQuest. Email to author Sept. 14, 2016.

Oliva, Victor. 2016. "Deselection of Print Monographs in the Humanities and Social Sciences in the Digital Age." Collection Building 35 (2): 37-47. doi.org/10.1108/CB02-2016-0002

Pidgeon, Alice. 1995. "On Writing a Deselection Policy; or, How to Toss Books Without Public Condemnation." Against the Grain 7: 68-69, 86.

Raphael, Laura. 2013. "Killing Sir Walter Scott: A Philosophical Exploration of Weeding." In the Library With the Leadpipe (blog). July 24. Accessed March 10, 2017. http://www. inthelibrarywiththeleadpipe.org/2013/killing-sir-walter-scott-aphilosophical-exploration- of-weeding/

Reich, Thomas. 2013. "Less Is More: Origins of University of Wisconsin-Stevens Point Collection Assessment Plan." Proceedings of the Charleston Library Conference. doi.org/10.5703/1288284315262

Roy, Loriene. 1988. "Does Weeding Increase Circulation? A Review of the Related Literature."Collection Management 10 (1-2): 141-156.

Slote, Stanley J. 1997. Weeding Library Collections: Library Weeding Methods, 4th ed. Englewood, CO: Libraries Unlimited.

Snyder, Cynthia Ehret. 2014. "Data-Driven Deselection: Multiple Point Data Using a Decision Support Tool in an Academic Library." Collection Management 39 (1): 1731.

Terruso, Julia. 2009. "Bird Library Book Removal Sparks Debate." The Daily Orange. Accessed March 10, 2017. http://dailyorange.com/2009/11/bird-library-book-removalsparks-debate/

Woolwine, David. 2014. "Collection Development in the Humanities and Social Sciences in a Transitional Age: Deaccession of Print Items." Library Philosophy and Practice (e-journal) Paper 1173. Accessed May 25, 2016.

http://digitalcommons.unl.edu/libphilprac/1173/

Young, Diane J. 2009. "Get to Effective Weeding." Library Journal 134 (19): 36 